TEACHERS STRATEGY IN TEACHING NARRATIVE TEXT AT SENIOR HIGH SCHOOL

AN ARTICKEL

BY:

ADE ELVINA HARIANJA

REGISTRATION NUMBER : 2123321001

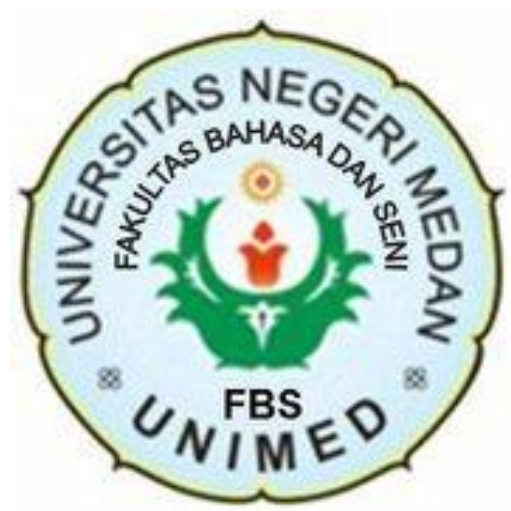

ENGLISH EDUCATION AND LITERATURE DEPATEMENT FACULTY OF LANGUAGES AND ARTS THE STATE UNIVERSITY OF MEDAN 2016 


\title{
ARTIKEL \\ TEACHERS STRATEGY IN TEACHING NARRATIVE TEXT AT SENIOR HIGH SCHOOL
}

\author{
Disusun dan Diajukan oleh: \\ Ade Elvina Harianja \\ NIM. 2123321001
}

Telah diverifikasi dan dinyatakan memenuhi syarat

Untuk diunggah pada jurnal online

Medan, September 2016

Menyetujui

Dosen Pembimbing Skripsi I

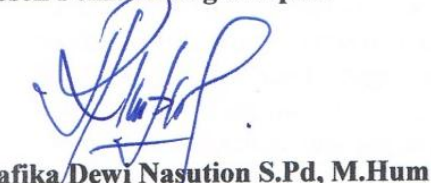

NIP.19780108200501 2033
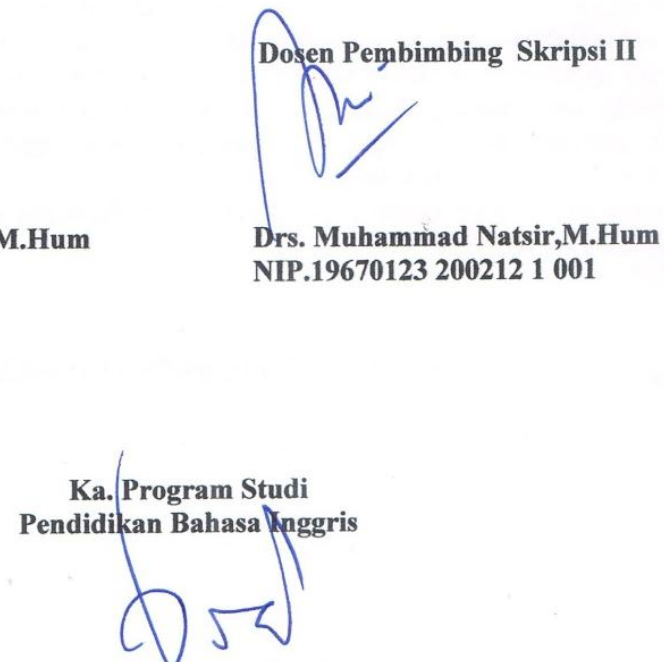

Nora Ronita Dewi, S.Pd., S.S., M.Hum.

NIP. 198005522008122003 


\title{
TEACHERS STRATEGY IN TEACHING NARRATIVE TEXT AT SENIOR HIGH SCHOOL
}

\author{
*Ade Elvina Harianja \\ **Rafika Dewi Nasution, S.Pd,M.Hum \\ **Drs. Muhammad Natsir,M.Hum
}

\begin{abstract}
Ade Elvina Harianja.2121123001. 2016. Teachers Strategy in Teaching Narrative Text at Senior High School. A Thesis Faculty of Language and Arts.State University of Medan
\end{abstract}

This study is a qualitative descriptive. This research was conducted by direct observation of English teachers. This research was conducted by direct observation of the teacher in the classroom and by interviewing. Researchers studied four English teachers and gave the same four questions to each teacher. Indicators of success include three English teachers use cooperative strategy. The results of this study showed that three out of four English teachers who are in SMA Negeri 1 OnanRunggu using cooperative strategies in the teaching of narrative text. That means that $75 \%$ of $100 \%$ choose to use a cooperative strategy. Thus, it is suggested that the english teachers apply strategy cooperative when teaching narrative text.

$\underline{\text { Key Words : Teachers Strategy,Teaching, and Narrative Text }}$

\author{
*Graduate Status \\ **Lecturer Status
}




\section{INTRODUCTION}

\section{Background of the Study}

Learning Model Cooperative Learning is one of learning model that supports contextual learning. Cooperative Learning Teaching system can be defined as a system of work / study group is structured. Included in this structure are the five basic elements (Johnson \& Johnson, 1993), which is positive interdependence, individual responsibility, personal interaction, skill work together, and the group process.

Cooperative learning is a teaching and learning strategy that emphasizes the attitudes or behavior in work or help among the regular cooperation structure within the group, which consists of two or more people.

Cooperative learning is a form of learning that is based on a constructivist ideology. Cooperative learning is learning strategy with a number of students as members of small groups of different ability levels. In completing the task group, each student group members to work together and help each other to understand the subject matter. In cooperative learning, learning is said to be unfinished if one friend in a group have not yet mastered the lesson material .

During the cooperative learning students remain in the group for a few meetings. They are taught specific skills to be able to work well together in the group, such as being an active listener, explaining to the group with good friends, discussing, and so forth. To be done well, students are given an activity sheet with questions or tasks that are planned to be taught. During his work in the group, task 
group members is to achieve mastery of the material presented teachers and mutual help among a group of friends to achieve mastery of the material. Learning not finished if one of the group members there who have not mastered the subject matter. Cooperative strategy is one of the main focus of this thesis. Cooperative learning is a teaching strategy that involves a group of students to work collaboratively to achieve a common goal (Eggen and Kauchak, 1996: 279). Cooperative learning is organized in an attempt to facilitate the students to experience leadership attitudes and make decisions within the group, as well as provide opportunities for students to interact and learn together students of diverse backgrounds. So in cooperative learning students play a multiple role as a student or as a teacher. By working collaboratively to achieve a common goal, then students will develop skills associated with their fellow human beings that will be very useful for life outside school

Language is a very important tool of communication that is used to communicate between two or more people in carrying out their daily activities and have a major role to make people understand. The function of language is not only for communication but also for the cultural transfer. English is the international language has been taught to studend of kindergarten, elementary, junior high, high school and also to University students. In English there are four skills that must be learned in learning English, they are Listening, Speaking, Reading and Writing. One of the skills the focus of this thesis, namely speaking. Speaking is one of the four language skills are hard part is listening, speaking, reading and writing. To enable us to speak, we should listen. And the same thing in writing, to make us 
able to write, we should be able to read and think a lot. Speaking is the act of conveying information or expressing one's feelings in a speech: clear thinking to help speak clearly. Action convey information or express one's feelings in a speech: clear thinking to help speak clearly. As well as in narrative learning, students are not just listening, writing and reading, but students can talk like a character in the narrative text. With clear spoken language while learning, it will be easier for students to understand and be interested in learning. A narrative story and narrative writing tells a story, when someone says "let me tell you what happened to me today," the person who started the narrative. Actually there are many ways to solve the above problem in improving their skills in speaking. There is one way to solve the problem with the method is suitable in using strategies teachers in the classroom. Situation this may be because it is less suitable strategy. So teachers must make variation's and choose a strategy that fits in teaching Speaking. As a teacher, author always think to solve problems encountered in the learning process and the lack of student understanding narrative texts and author find alternative methods of solving problems through think pair and share strategy.

\section{A. Problem Of The Study}

The problems in this study are stated as follows:

1. What the strategy use in teaching narrative text in SMA N 1 Onan Runggu?

2. What is the type of english teaching strategy used by teacher in SMA N 1 Onan Runggu ? 
B. The Scope Of The Study

The scope of this study to analyze teachers strategy in teaching narrative text

C. The Objectives Of The Study

The objectives of the study are to describe the teaching and learning process of teaching speaking to the tenth grade students of senior high school. The objectives of the study can be stated as follows:

a. To find out the type of strategy used in teaching narrative

b. To explain what is the strategy used in teaching narrative text.

D. Significance Of The Study

This study will be useful as follows:

1. To teacher, give a better solution in applying a better strategy in teaching process especially in teaching narrative text.

2. To students, can improve their ability to speak in class especially in narrative text and this strategy to make students interested. 


\section{REVIEW OF LITERATURE}

Initially the term used in the military strategy which is defined as the way of the use of all military power to win a war. A person who was instrumental in arranging the strategy to win the war before divulging action, will weigh how the force has good views of quantity and quality. Next, will collect information about the strength of the opponent, a good number of soldiers and weapons state. Once everything is known, and then it will draw up action what to do, both on tactics of warfare that must be done, tactics or techniques of warfare, as well as the right time to carry out an attack and so forth. Thus in developing the strategy needs to take into account factors, both inside and outside.

As Brewster, Ellis and Girard (2002:63) said that strategy is Children constantly need to recycle what they have learned so they don't forget, and to perceive progress, maintain motivation and aid memorisatio.

From the definition explained by the expert above, Children need to recycle what they have learned so that they are not forgotten, and to feel the progress, maintaining motivation and help memorize how to create a strategy that could make them not bored and happy while learning. 


\title{
RESEARCH METHODOLOGY AND FINDING
}

\author{
Methodology
}

This research was designed with descriptive qualitative research which describes and interprets what it is. As Creswell (2007) stated that descriptive qualitative research describes the phenomenon being studied, condition or relationship that exist. Processed that are going on or effects that being felt. Through this design, the description of teacher knowlodge of teaching speaking was clearly explained.

\section{Technique of Data Analysis}

In qualitative reseach the data godhered appear in words rather than in number. Data analysis is the process of systematically searching and arranging the interview transcrip. Observation transcript and other material that the researchers accumulated to increase her own understanding of them and to able to present.

Miles and Huberman (1984) the data analysis contains three linked subprocess, data reduction, data display, and conclusion drawing/verification .

With data reduction, the potential universe of data is reduced in an anticipatory way as the researcher chooses an conceptual framework ,research, questions, cases, and instruments. Data display, defined as an organized, compressed assembly of information that permits conlusion drawing and/or action taking, is a second, inevitable, part of analysis. Conlusion drawing and verification involve the researcher data.

The data obtained were analyzed as follow: 
1. Transcribing the recorded observation and recorded interview

2. Classifiying the identified data in accordance with the problem of the study

3. Drawing conclusion based on the interelationship of the data.

\section{Finding}

The results obtained english teacher interviews in narrative text material shows an increase learning outcomes and student activity and teacher activity for cooperative learning model. In addition, cooperative learning fun for students, where learning is the learning process takes place with the interaction with members of each group to discuss the material provided by the teacher, making it easier for students to obtain information and make students more skilled in expressing their opinion. With this model makes students feel interested and avoid boredom because after discussions they will be trained to learn independently as they would with a question of they own understanding.

From the research results obtained from the four English teachers showed that the strategy of co-operative selected by $75 \%$ of the teachers of the other strategies. The table shows that the cooperative strategy is better used in the study of narrative text. According to Roger (1992) cooperative learning is group learning activity organized in such a way that learning is based on the socially structured change of information between learners in group in which each learner is held accountable for his or her own learning and is motivated to increase the learning of other. 
Researchers found that teachers use cooperative strategies to see the results of student learning. Students can share with friends and split the opinion with other groups about an issue or a discourse that is contained in the narrative text. By the time they worked with a group they can exchange opinions and dare to speak to another group. 


\section{CONLUSION AND SUGGESTION}

\section{Conclusion}

After analyzing the data, the conlussions as drawn as follows:

1. There are $75 \%$ of teachers who choose to use cooperative strategies when teaching a narrative text.

2. Teachers chose a cooperative strategy for co-operative strategy makes students dared to speak to express their opinions of each and they were active in the lesson. Each person must learn all the course materials so that when other groups asked the group members already know the answer.

\section{Suggestion}

By considering the conclusion there are some suggestions which are presented as follow:

1. For Studends can to increase in activity and student learning outcomes using cooperative strategies. It shows that $75 \%$ of teachers use cooperative strategies in the teaching of narrative text.

2. For English teachers who want to implement learning through cooperative strategy should pay attention to the condition of students in the classroom as well as the allocation of time has been planned so that learning objectives can be achieved. 


\section{REFERENCES}

As creswell.2007. Research design Qualitative Quantitative and Mixed Methods Approaches.English.SAGE Publications.

Brewster, Ellis; and Girard . 2002 .The Primary English Teacher's Guide. London : Penguin.

Dick ,Carey.2001.Learning Strategy. (http://www.sciencedirect.com/science/article/pii/S036013159900024X) Accesed on june 20,2016

Isjoni.2011.Cooperative Learning. http://unmas-library.ac.id/wpcontent/uploads/2014/04/PDF-SKRIPSI.pdf. Skripsi Ny wayan darsini. Denpasar. Accesed on May 20,2016.

Istarani .2011.cooperative learning.Bandung : Nusa Media.

Johnson , Johnson.1993.Cooperative Learning. (https://www.ied.edu.hk/apfslt/v8_issue2/hoff/hoff3.htm). Accesed on June 19,2016

Lie.2010.Mempraktekkan cooperative learning di dalam kelas. Jakarta :

Gramedia.

Lungdren.1994.The cooperative Strategies Series.San Pransisco : The New Lexiton Press.

Lyman Frank.1981. cooperative learning.Bandung : Nusa Media

Marahimin .1994.Pengertian karangan narasi.Online.(http:// klubsastra.net/2015/11/).Accesed on April 20,2016.

Model Pembelajaran kooperatif.2011.Online (https://doc/10158335). Accessed on April 12, 2016.

Mieke Bal. 1985. Narratology introduction to the theory of narrative. London.KLS

Ngalimun. 2012. Strategi dan Model Pembelajaran. Banjarmasin: Scripta Cendekia.

Ngalimun, dkk. 2015. Strategi dan Model Pembelajaran. Yogyakarta: Aswaja Pressindo.

Nunan .1991.Speaking Ability. http://files.eric.ed.gov/fulltext/ED415692.pdf. Acced on May 23,2016 
Slavin.1995.cooperative learning.Bandung : Nusa Media.

Slavin. 2005. cooperative learning.Bandung : Nusa Media.

Tarigan. 1990. Definition of Speaking Skill.

http://rujukanskripsi.blogspot.co.id/2013/06/definition-of-speakingskill.html. Accesed on May 20,2016.

Wilson.1983. Definition of Speaking Skill.

http://rujukanskripsi.blogspot.co.id/2013/06/definition-of-speakingskill.html. Accesed on May 20,2016. 